\title{
'n Oorspronklike blik op menswees in twee dramas deur Philip Rademeyer
}

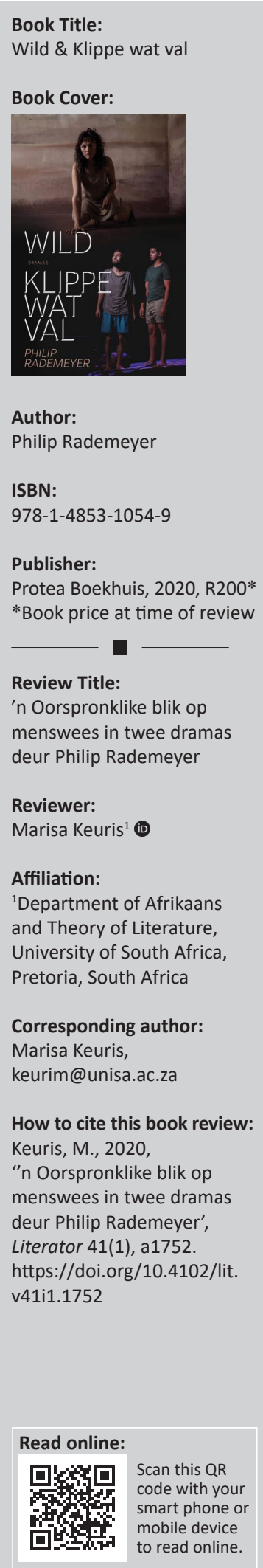

Philip Rademeyer is ' $n$ jong Suid-Afrikaner wat binne ' $n$ kort tydperk homself gevestig het as 'n besonder talentvolle teatermaker. Hy studeer in drama en teater by die Universiteit van Kaapstad en Ohio Wesleyan Universiteit, en is tans deeltydse dosent in die Dramadepartement van die Kaapstadse Universiteit. In 2012 vestig hy, saam met Penelope Youngleson, die Rust Co-Operative, en hulle produseer verskeie Engelse dramas (w.o. The view, Full stops on your face, The graveyard en Tee). Dit is nie net as dramaturg wat hy vinnig opgang maak en toekennings ontvang nie, maar ook as regisseur is hy baie aktief en word ook vir sy werk in hierdie genre bekroon. Twee van sy Engelse dramas The view (2013) en Siembamba (2017) is reeds gepubliseer.

Hoewel Rademeyer se Engelse dramas en sy regiewerk in Engelse produksies hom gevestig het in die Suid-Afrikaanse Engelse teaterindustrie, het hy ook deurgaans werk in Afrikaans gelewer. Hy word ook in Afrikaanse teaterkringe as 'n innoverende teaterpraktisyn gesien.

Wild is die eerste keer in 2017 op Stellenbosch (US Woordfees) opgevoer en wen verskeie toekennings, waaronder 'n kykNET Fiësta. 'n Jong meisie (moontlik deur honde grootgemaak en Vlooi gedoop deur die polisieman wat haar op 'n kleinhoewe vind), word deur hom in 'n hok aangehou by die polisieselle van 'n klein plattelandse dorpie. Die interaksie tussen hierdie wilde wese (meer dier as mens) en die polisieman (sy pogings om haar weer 'mens' te maak) word in drie 'trimesters' gegee, terwyl die slot aangedui word as die 'volgende dag' na die derde trimester in Augustus 1993 en wat as die 'geboorte' beskryf word.

Die koms van Ma in die tweede trimester verbreed die stuk se dramatiese inhoud en soos die polisieman (net benoem as Wag), vermoed die leser of toeskouer dat sy die biologiese ma van die meisie (haar dogter Annelise) is. Uit Ma en Wag se gesprekke kom 'n hartseer verhaal na vore van 'n ongelukkige huwelik, alkoholisme, mishandeling, die afsterwe van 'n babaseuntjie en die wegvlug van ' $n$ jong ma uit hierdie omstandighede, terwyl 'n klein dogtertjie agterbly.

Teen die agtergrond van hierdie inligting, bly die fokus in die drama hoofsaaklik op die interaksie tussen Wag en Vlooi. Hoewel sy pogings om haar meer mens (meer beskaafd) te maak 'n stadige proses vol frustrasies blyk te wees, word die leser of toeskouer reeds van die begin af bewus van 'n seksuele onderstroming binne hierdie verhouding, wat 'n mens bekommer. Ma konfronteer hom ook in die laaste trimester met die beskuldiging dat hy niemand anders (bv. opgeleide kenners) ingelig het van die meisie se bestaan nie, omdat hyself seksueel misbruik van haar maak, of wil maak. Haar woorde word profeties waar wanneer hy Vlooi teen die einde verkrag. Die 'geboorte' van Vlooi gaan ironies genoeg wel gepaard met die seksdaad, maar haar bekendstelling aan die wêreld van mense is traumaties: 'Sy huil vir die eerste keer soos 'n mens. Sy huil en huil en huil' (bl. 101).

Ook die tweede drama, Klippe wat val, is deur beide gehore en kritici goed ontvang. Dit wen die ATKV-Woordveertjie vir Dramateks in 2019 en word dieselfde jaar ook as radiodrama vir Radio Sonder Grense (RSG) verwerk.

Die hoofinteraksie is tussen Kannetjie, 'n verstandelik gestremde jong blanke man en Abrie, 'n bruin man van dieselfde ouderdom, wat saam grootgeword het op 'n afgeleë plaas, en wat mekaar weer na 15 jaar sien. Uit hierdie ontmoeting leer die leser of toeskouer die vroeë geskiedenis wat hulle op die plaas gedeel het, maar vanuit verskillende rasrealiteite. Kannetjie se pynlike verwerping deur sy ma word grotendeels verklaar deur haar eie trauma van verskeie miskrame en die geboorte van 'n gestremde kind, terwyl die verhouding met haar man verbrokkel het. In haar verbittering het sy al haar geloof in 'n liefdevolle God en hemelse wêreld verloor: vir haar is die verskietende sterre wat Kannetjie betower, geen wonderverskynsel nie,

Copyright: ( 2020 . The Authors. Licensee: AOSIS. This work is licensed under the Creative Commons Attribution License. 
maar slegs 'vallende klippe' met geen bonatuurlike betekenis nie. Abrie se eie grootwordjare op die plaas was traumaties as plaaswerkerkind en hy verlaat die plaas toe hy tot die besef kom dat hy die produk is van 'n gedwonge seksdaad en verkragting van sy ma deur Kannetjie se pa.

Die verhouding tussen Kannetjie en Abrie word gekenmerk deur empatie van die kant van Abrie, wat telkens Kannetjie se belewenis van die lewe en die dood (skaaplam, honde en mensegrafte) aan hom probeer verklaar. Ook hier verkry die klippe-metafoor verskeie betekenisse: skuiling versus geweldsimplement; klippe op aarde versus 'vallende klippe' uit die hemel. Terwyl Kannetjie se doodmaak van Abrie ten slotte deur 'n fisieke klippereën dus reeds uit vroeëre insidente in die drama aangekondig word, bly die slot skokkend en vir die leser of toeskouer ambivalent.
Kannetjie se ontoerekenbaarheid vir hierdie daad as gevolg van sy beperkte verstandelike vermoëns, beklemtoon juis ook sy onvermoë om die finaliteit van doodmaak te verstaan.

Albei dramas werk met boeiende temas, ongewone karakters en grys gebiede ten opsigte van die menslike kondisie. Die sterk konseptuele raamwerk van beide dramas is gebou op die jukstaposisie van 'n oënskynlik eenvoudige handelingsverloop in die hede, met 'n dieper onderstroom van donker geheime en emosies wat opwel uit die verlede.

In 'n jaar waarin die Covid19-pandemie die Suid-Afrikaanse teaterindustrie swaar getref het, is die eerste Afrikaanse publikasie van Philip Rademeyer se dramas ' $n$ besonder vreugdevolle gebeurtenis. 